\title{
Cinema for medical undergraduates
}

\section{Cine para estudiantes de medicina}

\author{
Alberto Enrique D’Ottavio \\ Facultad de Ciencias Médicas y Consejo de Investigaciones, Universidad Nacional de Rosario. Rosario (Argentina)
}

\section{Dear Editor}

Cinema may interact with Medicine confirming the way of life the students choose during their decision, guiding to undergraduates towards postgraduate options, and reinforcing their cultural background. Consequently, some films were selected from the Journal of Medicine and Movies (original initiative of the University of Salamanca) ${ }^{(1)}$ and the Internet Movie Database ${ }^{(2)}$ to be proposed. Regarding medical research and its competences are rescued: Arrowsmith (1931) an approach to microbiology, ethics and research, The story of Louis Pasteur (1935), Yellow Jack about Walter Reed, Carlos Finlay and col. and yellow fever transmission (1938), Robert Koch (1939), Dr. Ehrlich's Magic Bullet (1940), Madame Curie (1943), Semmelweis (1950), Freud (1962), Awakenings (1990) about Oliver Sacks and the benefits of L-Dopa in encephalitis lethargic patients, The Race for the Double Helix (1987) recalling a scientific rivalry after the discovery of DNA structure, And the band played on (1993) deals with Donald Francis and the discovery of the AIDS virus, Casas de Fuego (1995), about Dr. Salvador Mazza and his social contributions on Chagas' disease, Kindsey (2004) analyzes sexual human behavior, and The Constant Gardener (2005) addressing the complex debate on drug research. Regarding medical teaching and its competences are suggested: Doctor in the house (1954) a group of students coursing medical career, Almafuerte (1949) recalling an Argentinean poet and teacher, Blackboard Jungle (1955), To Sir, with love (1967) and Lean on me (1989), dealing with challenging social and educative problems in city high schools, Inherit the wind (1960) recreating John Scopes' trial for teaching Darwin's theory of evolution in a creationist ambit, Stand and Deliver (1988) remembering Jaime Escalante who turned a group of math failures into math geniuses, Dead Poets Society (1989), evoking to the inspiring teacher Samuel Pickering in a fictional and elite conservative academy, Finding Forrester (2000) teaching how pedagogic eros may appear not only in trained educators, and María Montessori, una vita per i bambini (2007), reflecting what she applied to children undergoing social risk. Finally, regarding medical care and its competences are proposed: The Citadel (1938) a cyclical and ethical personal transformation, Not as an stranger (1955) humanization versus dehumanization in medical practice, The boys from Brazil (1978), a hided Josef Mengele creates Hitler's clones for a dreamed Fourth Reich, The Elephant Man (1980), providing the relevance of empathy and compassion, Philadelphia (1993) confronting AIDS and human discrimination, Miss Ever's boys (1998), exploring the social and ethical consequences of the
Tuskegee Experiment, Patch Adams (1998) linking humor to pathos, Erin Brockovich (2000) a troubled mother facing a legal case of environmental contamination, Something the Lord Made (2004) treating medical interracial collaboration, Gifted Hands (2009) reflecting the feat of separating twins conjoined at the head, Albert Schweitzer (2009) and his ethical philosophy practiced in Africa, and The Physician (2013), a $11^{\text {th }}$ century travel to Persia for learning Medicine from Avicena. To conclude, Cinema and Medicine integrate a fruitful couple for different purposes leading teachers to choose the corresponding movie in accordance with the practice to be fostered.

\section{BIBLIOGRAPHICAL REFERENCES}

1. Journal of Medicineand Movies. In: http://revistamedicinacine. usal.es/es/ (Accessed December 26 2016)

2. Internet Movie Database. In: http://www.imbd.com/ (Accessed December 28 2016) 